\title{
Mechanical Properties of Guttapercha Point
}

\author{
Toshiaki Dobashi*1, Susumu Tanaka*1, Akio Sakanishi*1, \\ Nobuyuki HatToRi ${ }^{* 2}$, Izumi TAKenaka ${ }^{* 2}$, and Kazuo HiRota ${ }^{* 2}$ \\ ${ }^{* 1}$ Department of Biological and Chemical Engineering, Faculty of \\ Engineering, Gunma University, Kiryu, Gunma 376 Japan \\ ${ }^{* 2}$ Research and Development Department, G-C Dental Industrial Corp., \\ 76-1 Hasunumacho, Itabashi-ku, Tokyo 174 Japan
}

\begin{abstract}
Stress-strain curve was measured for guttapercha point, a dental material, using a tensile testing instrument. Effective strain was calculated with a simple correction based on Hooke's law. All the observed stress-strain curves were in substantial agreement at a low strain range, independent of the initial length. Young's modulus was determined to be $5.6 \times 10^{9} \mathrm{dyne} / \mathrm{cm}^{2}$ from the initial slope of the curve in dry state at the humidity of $49 \sim 68 \%$ at $24^{\circ} \mathrm{C}$. Both the yield stress and the yield strain decreased linearly with increasing initial length. In wet state at $20^{\circ} \mathrm{C}$ in Ringer's solution, the stress-strain curve was remarkably nonlinear and the yield strain in wet state was about twice as large as that in dry state. Increasing the temperature to $37^{\circ} \mathrm{C}$ at physiological state, the yield stress decreased to a third as large as that at $20^{\circ} \mathrm{C}$. Guttapercha plate showed an anisotropic stress-strain behavior depending upon the direction of extention in the manufacturing process. The Young's moduli for the sample stretched in the longitudinal and lateral direction were $8.3 \times 10^{9} \mathrm{dyne} / \mathrm{cm}^{2}$ and $13.3 \times 10^{9} \mathrm{dyne} / \mathrm{cm}^{2}$, respectively. Both of the moduli increased with the content of the filler in accordance with the theory by Guth. The larger values of the moduli in comparison with that of guttapercha point seem to be due to the difference in molecular orientation caused in the manufacturing process.
\end{abstract}

Key words : Dental material/Guttapercha point/Stress-strain curve/Filler effect

\section{ガターパーチャポイントのカ学的性質}

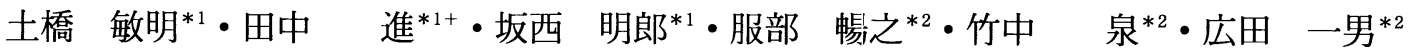

（原稿受理：1993年6月11日）

\section{1. 緒}

\section{言}

ガターパーチャポイントは歯髓を抜いた後の根管に充填される

${ }^{* 1}$ 群馬大学工学部生物化学工学科

于376 群馬県桐生市天神町 $1-5-1$

*2 ジーシー研究開発本部研究所

厂174 東京都板橋区蓮沼町 76 番 1 号

+ 現住所 $\overline{\mathbf{T}} 371$ 群馬県前橋市昭和町 3-39-22

群馬大学医学部生化学教室
歯科材料である．根管充填は，一般に外界からの感染経路を遮断 し，刺激汭歯周組織に及ぼされるのを防ぐためになされる ${ }^{1)}$. ガ ターパージャ(trans-ポリイソプレン)は口腔内における生化学的 な安定性に優れた封鎖性をるつため, 既に 19 世紀半ばから根管 充填剤として使用されてきた. 最近では操作性がよく充填しやす いようにラーパーが付けられたガターパーチャポイントが開発さ れ広く使用されている2) 4). 現在用いられている根管充塡法には 
側方加圧充填法と垂直加圧充填法がある ${ }^{5) \sim 7)}$. 前者は主ポイント を根管側壁に圧接して次に挿入するポイントの余地を作りこの隙 間に補助ポイントを挿入していく方法であり, 後者はポイントを 軽く加熱して軟化させ垂直方向に加圧して根管を封鎖する方法で ある.

ガターパーチャポイントの構成成分はマトリックスであるガ ターパーチャとフィラーとして含まれる酸化亜鉛である. 充填材 には補強材料としての適当な大きさの弾性と力学的強度が必要と されるが，その性状は一般にフィラーの量や製造の加工工程に依 存する. 現在用いられている材料は経験的に決められた配合比や 工程で造られているが，ょり良い材料の開発のためには材料解析 の方法を確立し系統的にこれらのパラメータを変えて調べる必要 がある。また臨床の実際におけるポイントの剛さあるいは柔らか さの微妙な調節は歯科医師の感覚や経験に委ねられることが多い が，むしろレオロジー的な解析によって定量的に調べておく必要 があると考えられる.

材料の力学的特性の評価は一般的には短冊型あるいはダンベル 型のプレート試験片を用いて行われる。一方, 現在普及している ポイントはリーマーやファイルと同一規格の太さをもつ円柱状の つかみ部とテーパー付きの先端部を持つため ${ }^{6), 7)}$, 通常の張力試 験の解析方法をそのまま用いることはできない，本研究では実用 のポイントに対する解析方法を示すと共に室温およびリンゲル液 中における温度依存性の測定結果について検討する．また製造行 程の比較的簡単なプレート試験片を用いてフィラーの配合比に対 する弾性率の依存性を調べる.なおプレートは適当な形に切り とってポイントの補助のために使う歯科材料として実用されてお り, その弾性率の值を求め異方性を調べることはそれ自体有用で ある.

\section{2. 実 験}

\section{(1) 試料}

ガターパーチャポイントは而至歯科工業社製で，ISO（国際標 準化機構）規格の No.50である. 試料に含まれるガ夕ーパーチャ は, trans-1，4 結合をあつポリイソプレンが $99 \mathrm{~mol} \%$ のので結 晶化度 $\chi$ は 0.36 である. フィラーである酸化亜鉛の平均粒子径 $d$ は約 0.5 ミクロンである. 配合比はガターパーチャ $15 \mathrm{wt} \%$, 酸化 亜鉛 $85 \mathrm{wt} \%$ である. 形状を Fig. 1a に示す. 試料 50 例の平均よ り得られた大きさは円柱部分の太さ $d$ が $(0.77 \pm 0.01) \mathrm{mm} \phi$, テー パーの先端部分の太さ $(0.45 \pm 0.01 \mathrm{~mm}) \phi$, 全長 $(29.96 \pm 0.07) \mathrm{mm}$ あった。 また，角 $\theta$ は $1.2^{\circ}, x_{0}$ は約 $38 \mathrm{~mm}$ であった。張力試験にお いて円柱部分の長さ $x_{2}-x_{0}$ は $8 \mathrm{~mm}$ ，テーパー部分のチャックの位 置 $x_{1}$ は, $x_{2}-x_{1}$ が $12 \mathrm{~mm}, 16 \mathrm{~mm}$ および $20 \mathrm{~mm}$ となる 3 点を取った。 そ れぞれについて室温 $24 \pm 1^{\circ} \mathrm{C} ， 49 \sim 68 \% \mathrm{RH}$ の空気中(ドライ状 態) と, $20.0 \pm 0.5^{\circ} \mathrm{C}, 37.0 \pm 0.5^{\circ} \mathrm{C}$ よび $50.0 \pm 0.5^{\circ} \mathrm{C}$ のンゲル液中 （ウェット状態）で張力測定を行った．なお，ウェット状態での測 定は各温度で 30 分間保生した後行った。

プレート試験片の規格は，Fig. 1b に示す JIS の K6301 の 2 号 である. 平行部分の幅は $10 \mathrm{~mm}$, 長さ $20 \mathrm{~mm}$, 厚さ $0.7 \mathrm{~mm}$ である. ダン ベル型試験片は, ガターパーチャと酸化亜鉛の混合試料をロール によって圧延してプレート状にしてから，JIS 規格の大きさに型 抜きをして得た．ここでロールの圧延方向に切り取った切片を L 方向の切片とし，それと垂直な方向を $\mathrm{S}$ 方向とした. 試料として (a)

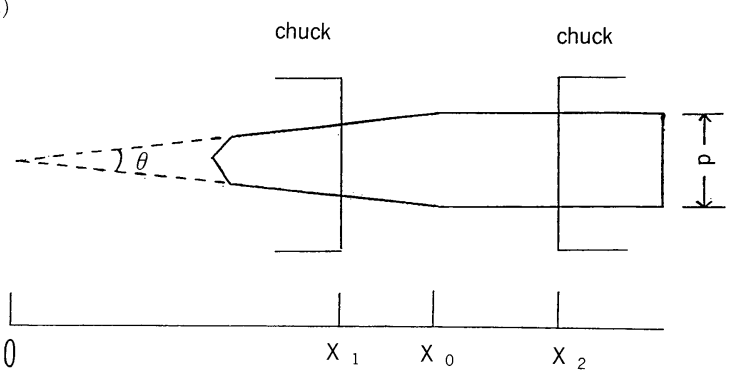

(b)

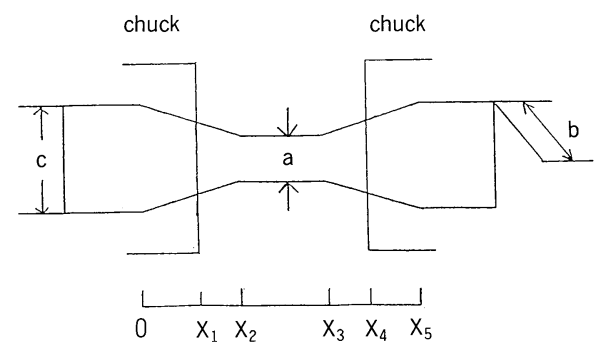

Fig. 1 Illustration of guttapercha point (a) and plate (b)

酸化亜鉛の配合比が $10 w t \%, 30 w t \%, 50 w t \%, 70 w t \%, 78 w t \%$, $85 \mathrm{wt} \%, 88 \mathrm{wt} \%$ の 7 種類を用意し, それぞれ L 方向と $\mathrm{S}$ 方向に ついてドライ状態で張力試験を行った。 またガターパーチャポイ ントと同じ配合比である酸化亜鉛 $85 \mathrm{wt} \%$ の短冊型のサンプルを 用いて圧延方向 L に対する角度 $\theta=30^{\circ}$ と $60^{\circ}$ に切り出した試料 についても同様な張力試験を行った。

張力試験にはテンシロン張力試験機（UTM-4L，オリエンテッ

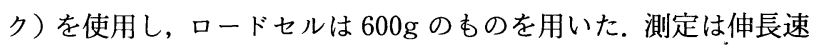
度 $5 \mathrm{~mm} / \mathrm{min}$ で定速伸長して行った. また, ウェット状態における 測定值には浮力の補正を行った。 ロードセルからの電気信号はア ンプで増幅し，チャートコントローラ(AR6000，オリエンテッ ク)によりプロットするとともに, デジタルマルチメータ（TR 6845 , アドバンテスト)を介してパーソナルコンピュータ（PC 8801-FR, NEC)に 0.2 秒ごとに取り込み, ディスケットに記憶さ せた。

\section{(2) 解析方法}

Fig. 1a においてチャックの片端 $x$ が試料のテーパー部分にあ るとき, $x$ における断面積 $S(x)$ は定数 $k$ を用いて $S(x)=k x^{2}$ と 表される. 一方, 円柱部分にあるとき $S(x)$ は一定であり, $S(x)=$ $S_{0}=k x_{0}{ }^{2}=\pi d^{2} / 4$ である. フックの法則が成り立つ小さなひずみ の範囲内では, 張力 $F$ はヤング率 $E$ と伸び $u(x)$ を用いて次式で 表される。

$$
F=E S(x) d u(x) / d x
$$

したがって, $u(x) を x_{1}$ から $x_{2}$ まで積分することによって次式が 得られる。

$$
u=\left(F / E S_{0}\right)\left(x_{0}{ }^{2} / x_{1}+x_{2}-2 x_{0}\right)
$$

ここで式(2)のカッコ内 $\left(x_{0}{ }^{2} / x_{1}+x_{2}-2 x_{0}\right)$ を $\ell$ すると, $\ell$ は $\ell=$ $\left(x_{0} / x_{1}\right) \ell_{1}+\ell_{2}$ と変形される.ここで $\ell_{1}$ はテーパー部分の長さ $x_{0}-x_{1}, \quad \ell_{2}$ は円柱部分の長さ $x_{2}-x_{0}$ である.このときひずみを $r=u / \ell$

と表すと, 応力 $\sigma$ は通常の関係式 $\sigma=F / S_{0}=E \gamma$ で表される.

プレート試験片についても Fig. 1b に示すように座標をとり, 
実験条件の $x_{2}=x_{5}-x_{3}, x_{2}-x_{1}=x_{4}-x_{3}$ を用いて次式を得た。

$$
\begin{aligned}
u= & (F / a b E)\left\{\left(x_{3}-x_{2}\right)+\left\{2 a x_{2} /(c-a)\right\} \log \mid\right. \\
& \left.(a-c+1) x_{2} /\left\{(a-c) x_{1}+x_{2}\right\} \mid\right\} \\
\ell= & \left(x_{3}-x_{2}\right)+2 a x_{2} /(c-a) \log \mid(a-c+1) x_{2} / \\
& \left\{(a-c) x_{1}+x_{2}\right\} \mid
\end{aligned}
$$

以下の解析はこのようにして得られるひずみを用いて行った。

\section{3. 結果と考察}

ドライ状態においてガターパーチャポイントの初期長を変えて 測定した応力 - ひずみ曲線を Fig. 2 に示す.ひずみの小さな範囲 では初期長に依存せず同一の直線となる。この直線の傾きから初 期弾性率 $E=5.6 \times 10^{9} \mathrm{dyne} / \mathrm{cm}^{2}$ が得られた。 フックの法則から 外れる高ひずみにおいてもこれらの曲線は良好な一致を示してい

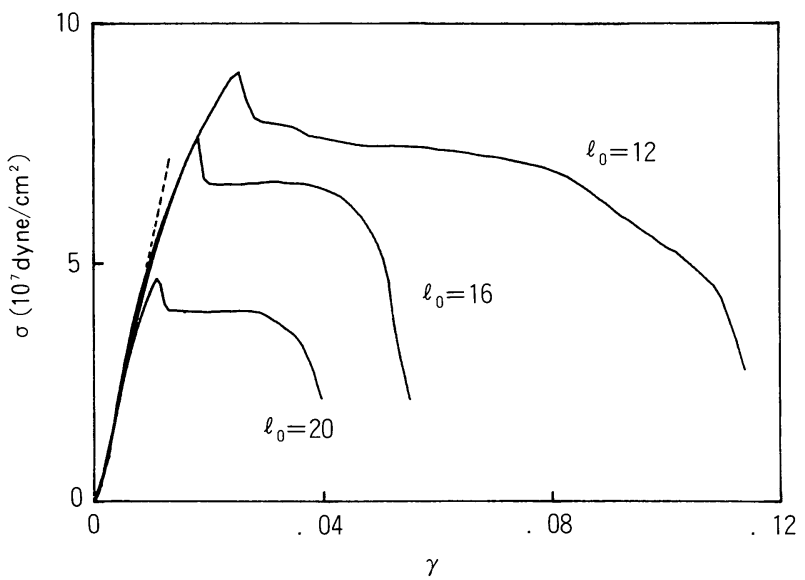

Fig. 2 Stress-strain diagrams for guttapercha point with various initial lengths in $\mathrm{mm}$ at dry state

る. また降伏応力を超えても応力は直ちに減少しないネッキング が見られた。ネッキングは熱可塑性高分子特有の性質であり, 結 晶性高分子はガラス転移点以上融点以下の温度で生じることが知 られているが8), 室温におけるガターパーチャはちょうどその領 域にある. 図中の降伏点における円柱部分の応力とその点におけ るひずみは, 最初のチャック間距離の増加とと屯にほぼ直線的に 減少した. しかし, 応力集中するはずである断面積最小部分での 応力を降伏応力と定義し, 実测值よりこれを求めると, 最初の チャック間距離によらず $10.7 \pm 0.8 \mathrm{dyne} / \mathrm{cm}^{2}$ となり，一定の応力 で塑性変形が発生していることがわかる，一方，歯科材料の評価 の際に一般に行われるように, 試料の一部にテーパー部分が存在 することを考慮にいれない場合，すなわちひずみとして伸び $u$ を 最初のチャック間距離 $\ell$ 。で割ったものをとると，ひずみ值は式 (3)で得られる值よりあ最大で約 $25 \%$ 程度小さい值を示す。この見 かけのひずみを用いて得られる応力 -ひずみ曲線はひずみの小さ い領域であも。に依存して異なる。

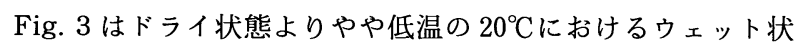
態の測定結果である. ウェット状態ではドライ状態より非線形性 が大きく, 初期弾性率は著しく小さくなっている。 また降伏応力 にはほとんど違いがないが, その点におけるひずみは約 2 倍に増 加している. ガターパーチャポイントを 30 分間リンゲル液に保 生した前後の重量を比較すると, 保生後の方が約 $0.02 \%$ 増加して
おり, 水分のわずかな増加がこのような変化をあたらすあのと考 えられる，Fig. 4 は $\ell_{0}=12 \mathrm{~mm}$ にける温度依存性である. 温度 $37^{\circ} \mathrm{C}$ と $50^{\circ} \mathrm{C}$ 降伏応力は $20^{\circ} \mathrm{C} お け る$ 最大応力のそれぞれ約 $1 /$ 3 と $1 / 6$ に減少している. また初期弾性率も温度増加とともに著 しく小さくなる.

Fig. 5 にドライ状態とウェット状態における降伏応力 $\sigma_{\max }$ と その点におけるひずみ $\gamma_{\text {max }}$ を报に対してプロットしたものを示

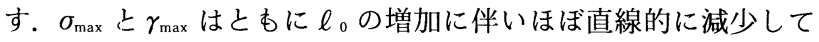
おり，ポイントの破断がテーパー部分のつかみ位置に大きく依存 することがわかる．また温度の上昇とともに $\sigma_{\max }$ は顕著に減少 し, $\gamma_{\max }$ は大きく増加した. ガターパーチャの融点は $52 \sim 54^{\circ} \mathrm{C}$ と 比較的低く, 温度による影響が大きく現われたものと考えられ る. ポイントは $35^{\circ} \mathrm{C}$ 付近より膨張を開始し, 約 $50^{\circ} \mathrm{C}$ 付近において 最大の大きさとなる傾向があるという報告あある7.

次に Fig. 6 に式(3)，(5)で与えられるひずみ $\gamma$ を用いて得られた 酸化亜鉛 $50 \mathrm{wt} \%$ のプレート試料の L 方向と $\mathrm{S}$ 方向の応力 -ひず み曲線を示す． S 方向では大きなネッキングを示した．またその 最大応力は $\mathrm{L}$ 方向の約 $1 / 3$ で, 一方その点におけるひずみは 3

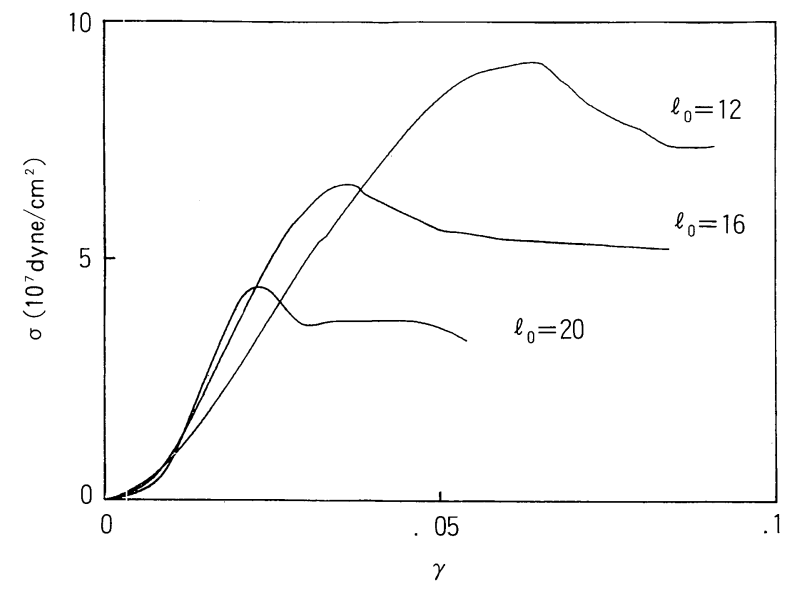

Fig. 3 Stress-strain diagrams for guttapercha point with various initial lengths in $\mathrm{mm}$ at $20^{\circ} \mathrm{C}$ at wet state

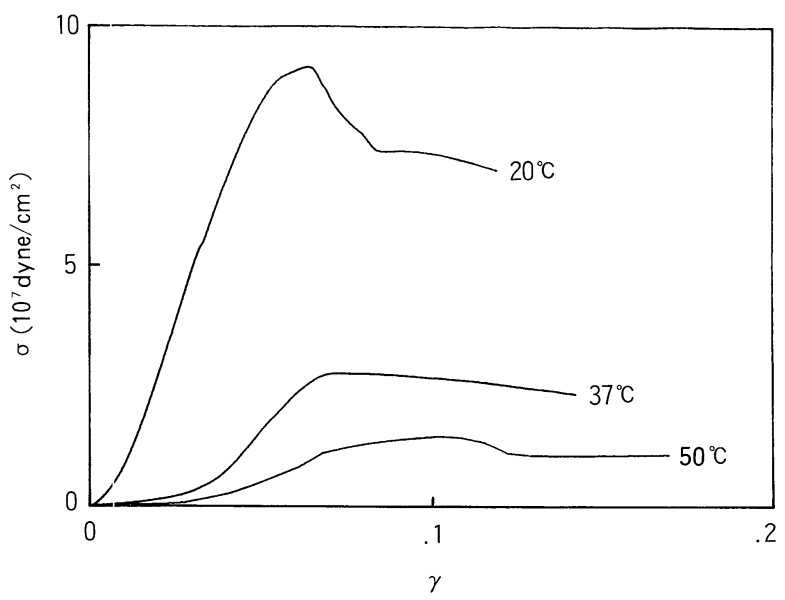

Fig. 4 Stress-strain diagrams for guttapercha point with initial length $\ell=12 \mathrm{~mm}$ at wet state at various temperatures 
倍の值を示し, 著しい異方性があることがわかる.この傾向は酸 化亜鉛の配合比が減少するにとあない顕著に現われる。これらの 現象はロールの圧延により L方向に試料が大きく延ばされるた めその方向に分子がそろって最大応力が増したためと考えられ

(a)

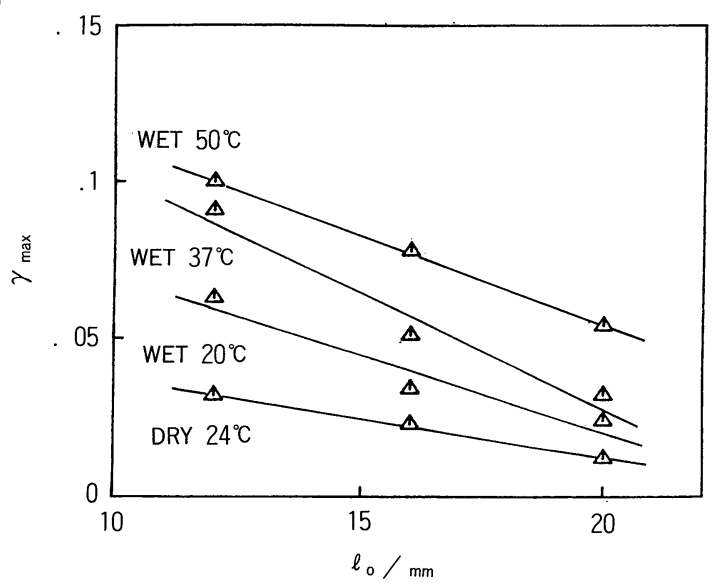

(b)

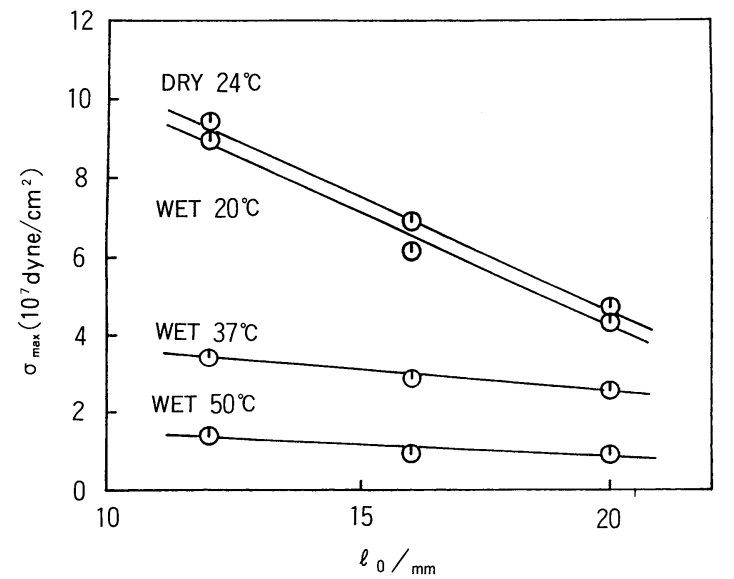

Fig. 5 Maximum strain (a) and maximum stress (b) of guttapercha point as a function of initial length

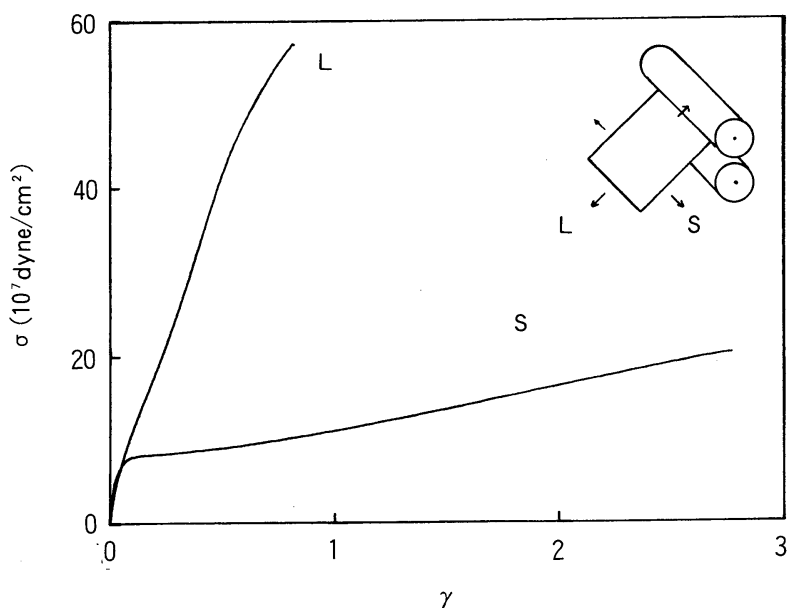

Fig. 6 Stress-strain diagrams for guttapercha plate with weight fraction of zinc oxide 0.5
る. Fig. 7 は種々の配合比における L 方向と S 方向の応力 - ひず み曲線の初期の部分を表したものである. ガターパーチャポイン 卜とそれと同じ配合比 $85 \mathrm{wt} \%$ で造られたプレートの初期弾性率 を比較してみると，ポイントで $E=5.6 \times 10^{9} \mathrm{dyne} / \mathrm{cm}^{2}$ であった のに対し，プレートでは L 方向で $E=8.3 \times 10^{9} \mathrm{dyne} / \mathrm{cm}^{2}, \mathrm{~S}$ 方向 で $E=13.3 \times 10^{9} \mathrm{dyne} / \mathrm{cm}^{2}$ であり，ポイントの初期弾性率はプ レートに比べて小さな值を示す．応力 - ひずみ曲線の形あ大きく 異なっている.これは射出成形によりつくられるポイントと延伸 行程を含むプレートでは試料の結晶化度および分子配向が異なる ことによるあのと考えられる.

フィラーの含有率を上げると初期弾性率は $\mathrm{L}, \mathrm{S}$ 両方向とも増 大し, 特に重量分率が $50 \mathrm{wt} \%$ 以上では初期弾性率が著しく大き くなった．ガターパーチャポイントには $85 \mathrm{wt} \%$ という高い比率 で酸化亜鉛が混合されていることから，わずかな配合比の変化に よって力学的な性質の異なる材料が得られることがわかる. L方 向と S 方向の比較においては, よ゙の配合比でも $\mathrm{S}$ 方向の方が初期 弾性率は大きい。

一般に酸化亜鉛はゴム状物質の弾性率や破断応力を増大させる ことが知られている ${ }^{9}$. Guth の理論(0)によればフィラーを含むア モルファス物質の初期弾性率 $E$ はフィラーの体積分率 $\phi$ の関数 として次のように表される.
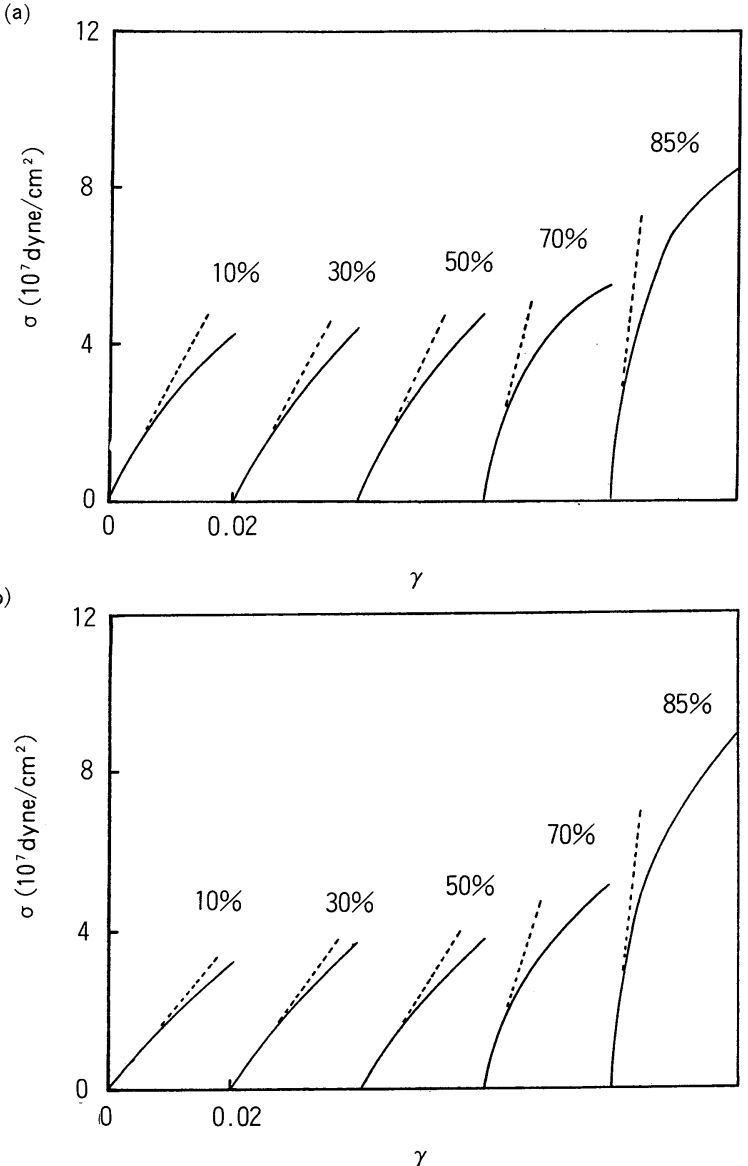

Fig. 7 Stress-strain diagrams up to $\gamma=0.02$ for guttapercha plate stretched in longitudinal (b) and lateral direction (a) with various weight fraction of zinc oxide. 




Fig. 8 Initial elastic modulus as a function of volume fraction of zinc oxide in guttapercha plate. Circles and lozenges denote $\mathrm{L}$ and $\mathrm{S}$ direction, respectively. Broken curves are those calculated by Guth theory of Eq.(6) with $E_{0}=1.47 \times 10^{9} \mathrm{dyne} / \mathrm{cm}^{2}$ and $2.51 \times 10^{9}$ dyne $/ \mathrm{cm}^{2}$, for $\mathrm{L}$ and $\mathrm{S}$ directions, respectively.

$$
E=E_{0}\left(1+2.5 \phi+14.1 \phi^{2}\right)
$$

ここで $E_{0}$ は $\phi=0$ における初期弾性率である.フィラーの重量分 率と酸化亜鉛の密度 $5.78 \mathrm{~g} / \mathrm{cm}^{3}$ および trans-イソプレンの密度 $0.96 \mathrm{~g} / \mathrm{cm}^{3}$ を用いてフィラーの体積分率を計算し， $E$ と $\phi$ の関係 から最小二乗法により $E_{0}$ を求めると L 方向では $1.47 \times 10^{9} \mathrm{dyne} /$ $\mathrm{cm}^{2}$ であり, $\mathrm{S}$ 方向では $2.51 \times 10^{\circ} \mathrm{dyne} / \mathrm{cm}^{2}$ であった．得られた $E_{0}$ を用いて式(6)から得られる計算曲線之実測值を比較すると Fig. 8 のようになる. 試料として用いたガターパーチャは Guth の理論が対照としている系とは異なり結晶性高分子であるにあか かわらず，計算曲線は実験值をかなり良く再現していることは興 味深い.

次にロールの圧延方向に対して $30^{\circ}$ と $60^{\circ}$ の角をなす方向にお いて短冊型試料を用いて行った応力 - ひずみ曲線を Fig. 9 に示

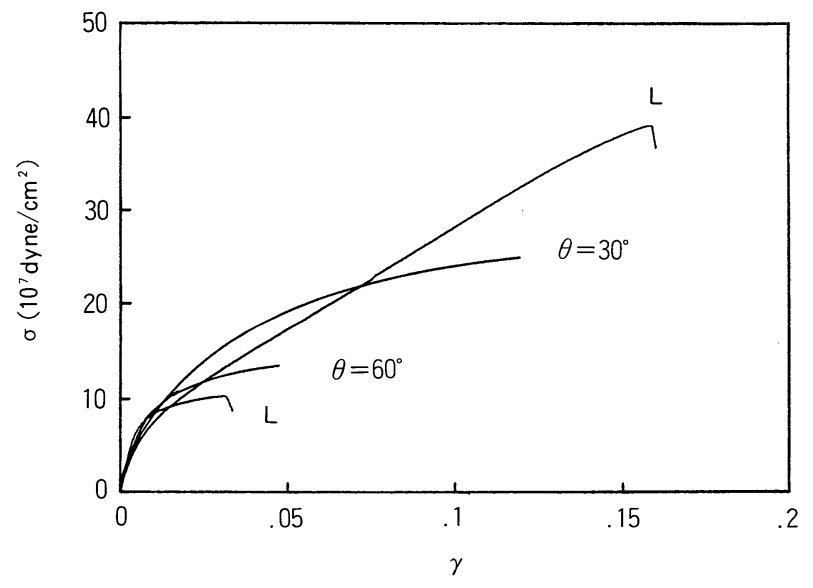

Fig. 9 Stress-strain diagrams for rectangular strips excised from guttarpercha plate in various directions with $85 \mathrm{wt} \%$ zinc oxide

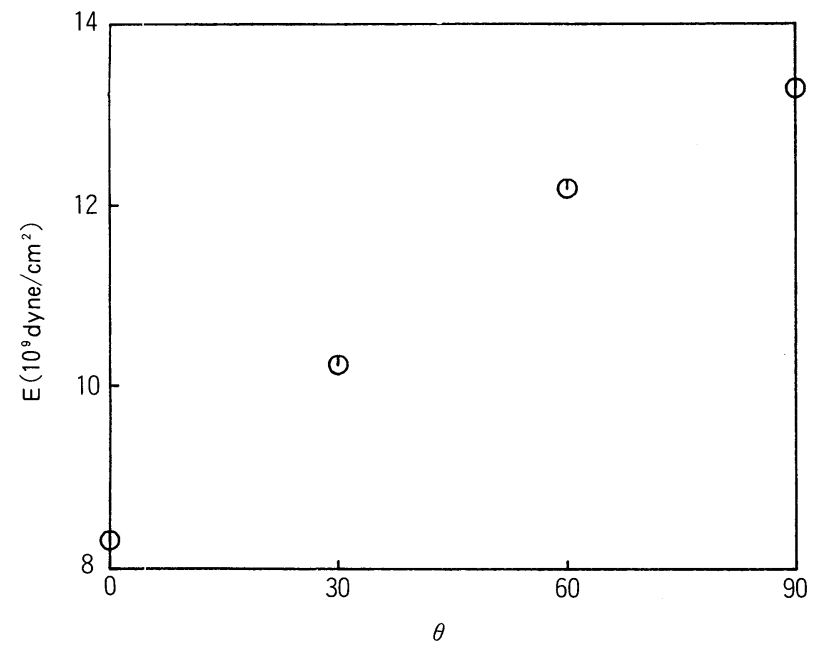

Fig. 10 Initial elastic modulus of guttapercha plate excised in various directions

す.これは酸化带鉛 $85 \mathrm{wt} \%$ の試料を用いたあのである. $\theta=30^{\circ}$ 方 向では L 方向と比較して最大応力およびその点におけるひずみ は減少した. $\theta=60^{\circ}$ 方向ではさらに最大応力およびその点におけ るひずみは低下し, S 方向の曲線に近づいた。 またそれぞれの曲 線から得られた初期弾性率は, Fig. 10 に示すように角度の増加 と共に増加した. また, $\theta=30^{\circ}$ および $\theta=60^{\circ}$ 方向の試料は伸長破 壊時において $\mathrm{S}$ 方向に対して垂直な方向で破断した.これは $\mathrm{S}$ 方 向に伸長したときの破壊時の角度に等しく, $\mathrm{S}$ 方向の破断応力が 一番小さいためこの角度で破壊したあのと考えられる. 現在, 根 管充填剤には主にガターパーチャポイントが使用されてはいる が, 依然々してポイントの補助としてのプレート状のガターパー チャに対する依存度も大きい. プレートから切り出して試料を用 いる場合には製造工程の圧延方向に注意して行う必要があると思 われる.

\section{4. ま と め}

歯科材料ガターパーチャポイントの応力 - ひずみ曲線の解析か ら初期弾性率を求め, 試験の行いやすいドライ状態と生理的状態 に近いウ:ット状態における值が大きく異なること, 温度をあげ ると破断応力が著しく減少することが見いだされた，ポイントの 補助材料にして使われるプレートを用いたフィラーの体積分率に 対する弾性率の変化の測定結果は Guth の理論でよく表された. ポイントに用いられている $85 \mathrm{wt} \%$ 付近の含有率ではフィラーの 量のわずかな変化によって大きく弾性率が変化する. またプレー トから切り出した試料は切り出す方向により力学的性質が異なる ので注意して扱う必要がある.

\section{文献}

1) Grossman LI, "Endodontic Practice" (1971), Lea and Febiger, Philadelphia.

2) Mayne JR, Shapiro S, Abramson II, Oral Surg, 31, 280 (1971).

3）長田保，“歯科展望 別冊 エンドドンティックスの臨 床”(1980), 医歯薬出版, p.162. 
4) Wong M, Peters DD, Lorton L, Bernier WE, J Endod, 8, 4 (1982).

5）平嶺勝嗣, 日本歯科保存学会誌, 26, 741 (1983).

6）平田恵美子, 鳥越敏博, 長沢恒, 日本歯科保存学会誌, 21, 214 (1978).

7）宗洋一郎, 日高理智, 唐木良一, 山本博武, 九州歯会誌, 35, 388 (1981).
8）飯田昌造, “高分子実験学 10 力学的性質 II ”, 高分子学 会高分子実験学編集委員会編 (1983), 共立出版, p.328.

9) Smallwood HM, J Appl Phys, 15, 758 (1944).

10) Guth E, J Appl Phys, 16, 20 (1945). 